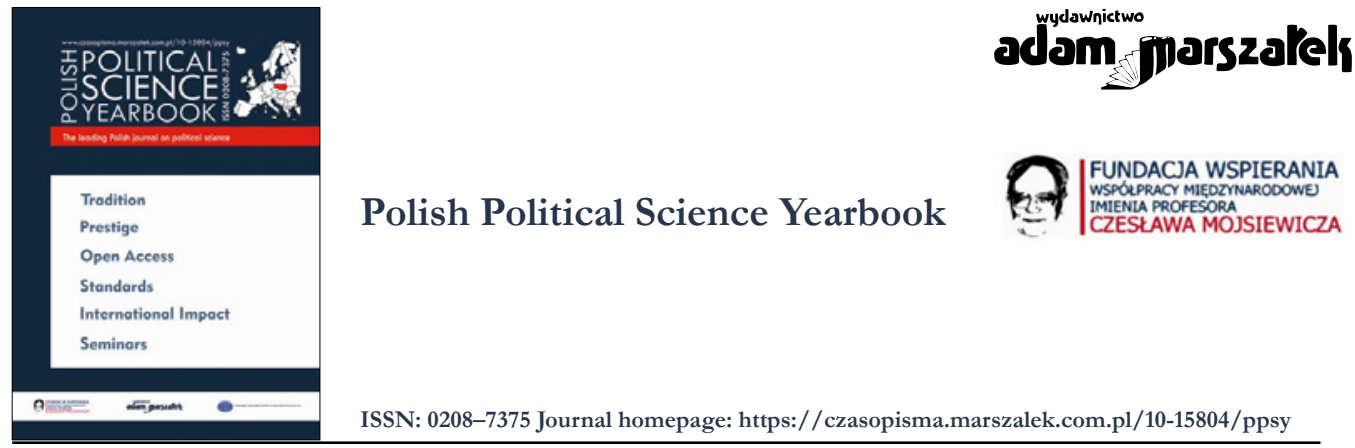

\title{
Common Security and Defense Policy of the European Union Through the Prism of Polish Experiences and Security Interests
}

\author{
Teresa Usewicz ${ }^{1}$, Kinga Torbicka ${ }^{2}$, Magdalena El Ghamari ${ }^{3}$ \\ ORCID: 0000-0001-6234-224X1, 0000-0002-6625-5060², 0000-0001-5798-7545³
}

To cite this article please include the following information:

- Journal title: Polish Political Science Yearbook

- Volume number: 50

- Year of publication: 2021

- Published ahead-of-print

Example styles:

[APA Style]: Usewicz, T., Torbicka, K., \& El Ghamari, M. (2021). Common Security and Defense Policy of the European Union Through the Prism of Polish Experiences and Security Interests. Polish Political Science Yearbook, 50 (issue number), pages. https://doi.org/10.15804/ppsy202149

[Chicago Style]: Teresa Usewicz, Kinga Torbicka, Magdalena El Ghamari, “Common Security and Defense Policy of the European Union Through the Prism of Polish Experiences and Security Interests" Polish Political Science Yearbook 50, no. [issue number] (2021).

To link to this article: https://doi.org/10.15804/ppsy202149

Published ahead-of-print

Final submission: 8 August 2021

Published online: 18 October 2021

Printed issue: 2021

Submit your article to PPSY 


\title{
Teresa Usewicz
}

Polish Naval Academy (Poland)

ORCID: 0000-0001-6234-224X

e-mail: t.usewicz@gmail.com

\section{Kinga Torbicka}

University of Warsaw (Poland)

ORCID: 0000-0002-6625-5060

e-mail: kinga.torbicka@uw.edu.pl

\section{Magdalena El Ghamari}

Collegium Civitas (Poland)

\section{Common Security and Defense Policy of the European Union Through the Prism of Polish Experiences and Security Interests}

\begin{abstract}
In this paper, the authors attempt to prove that the Polish position on developing the EU's Common Security and Defense Policy (CSDP) was skeptical, despite entries in political and strategic documents which emphasized its great significance for Polish security policy. It is evidenced by Poland's low level of involvement in EU missions and operations and other undertakings in the CSDP area. The central hypothesis adopted at the beginning of the research is that Poland has always treated security and defense within the European Union as a kind of complement to the potential and capabilities developed within the framework of the North Atlantic Alliance, and the Polish involvement in CSDP has never been adequate to the provisions contained in political and strategic documents. Poland's stance resulted, on the one hand, from the weakness of the CSDP's political framework, which was shaped by numerous compromises among its member states, and on the other hand, from the political elite's conviction that only NATO's, and de facto the United States', security guarantees are credible. In this paper, the authors analyze Poland's previous experience resulting from polish participation in the policy in question and the evolution of Poland's position toward its development in the context of the Republic of Poland's security interests formulated in political and strategic documents.
\end{abstract}

Keywords: European Union, Common Security and Defense Policy, Poland, security interests 
The Common Security and Defense Policy of the European Union is reflected in both Polish and international scientific sources. The Polish prism of these experiences and security interests is described mainly by authors coming from various research centers, both those related to the sciences of security and defense and political sciences, including Aleksandrowicz (2011), Zięba (2012), Żurawski vel Grajewski (2012), Ciupiński (2014), Koziej (2011), and the subchapter Kuźniar entitled Politics and Strength. Introduction to the 2006 Strategic Studies, which is devoted to the European Security Strategy. Jacek Czaputowicz, the Minister of Foreign Affairs of Poland, also writes about the subject matter (Czaputowicz, 2012). Interesting analyses, complementing scientific exploration, can also be found in numerous scientific articles, including Kuźniar, Gotkowska (2017), Madej and Terlikowski (2013), Terlikowski (2017), and Usewicz (2017).

International scientific sources indicate numerous analyses in monographs, articles, and messages, e.g., the works by Britz (2016) and Heisbourg (2000).

Several intriguing scientific inquiries can be found in the articles by the Ministers of Foreign Affairs and Defense: Wallström and Hultqvist (2017), Juncker and Sobotka (2017), Chappell (2020), Biscop (2017), Tard (2017), or Posen (2010).

Another, equally important from the research perspective, materials related to CSDP are statements of the Policy Department, which is part of the Directorate-General for External Policies of the EU, on missions and operations and the EU's Battle Groups, the European Parliament's communications from the European Commission, the Council of the European Union, or strategic documents for this. Based on the verification of existing sources, the main goal of the presented scientific article is to identify Poland's experience to date resulting from participation in the Common Security and Defense Policy and to evolve Poland's position toward its development in the context of the security interests of the Republic of Poland formulated in political and strategic documents. The research problem, motivated authors to research in the area of the Common Security and Defense Policy of the European Union, boils down to an attempt to answer questions about the overall approach of Poland to the policy in question and to verify the actual involvement of Poland in the light of the provisions contained in political and strategic documents in the area of safety.

The research questions identified at the initial stage of the research procedure come down to the following questions:

- How has Poland's approach to CSDP development evolved after 1989?

- Can Poland's to-date involvement in CSDP activities be assessed as sufficient in the context of security interests formulated in political and strategic documents?

The research questions were divided by the authors of the work into exploratorydescriptive research and research explaining what, in their opinion, exhausts the needs of the research procedure used, consisting of the formulation of the problem situation in the introduction to the article, the definition and recognition of research problems, collecting source materials, developing a research procedure, and selecting research methods. Techniques and tools, formulation of hypotheses are presented in this section. Chapter 1 of the 
article conceptualized the research, and a precise conceptual apparatus was created, used in the following chapters. Chapter 2 provides the analytical framework as well as discusses the methodological aspects of the article. Do the following subsections concern Polish perception of security and defense policy in the EU in political and strategic documents, Poland's approach to building EU military capabilities, and the attempt to answer whether Poland is only a consumer or a producer of security within the EU? The article ends with a summary of the obtained research results.

As a result of the methods used, a comprehensive picture of the examined issues was obtained. Theoretical research was organized and conducted, and the hypotheses were verified. In the last stage of the research, the results were verified and developed in a synthetic form in the phase of materials development. This procedure made it possible to summarize the fundamental research and the final editing of this scientific article. The use of the presented methods: analysis, exemplification, synthesis, induction and deduction, verification, and conceptualization is justified due to the interdisciplinary nature of the research. In research methods, research tools and techniques were used, respectively, according to the course of study and the assumed goal, including qualitative, critical and elementary analysis, causal association, and formulation of axioms.

The authors consider the level of implementation of the objectives adopted in the subject matter area in the Treaty on European Union, in Art. 42, according to which the common security and defense policy is an integral part of the common foreign and security policy. It provides the Union with an operational capacity drawing on civil and military assets. The Union may use them for peacekeeping, conflict prevention, and strengthening international security missions outside the Union, in line with the principles of the United Nations Charter. These tasks are performed based on the capabilities provided by the Member States.

The analysis of the problematic situation forced the authors to generate hypotheses, which were verified in the substantive part of the presented scientific article.

In the opinion of the authors of the study, the recent activities of the European Union under the CSDP aim to increase the EU's. The EU's reactivity to international crises and fighting other identified threats to EU countries often generated far beyond the borders of the Union, including the fight against terrorism on an international scale. Although the Treaty allows for establishing a common defense, no such decisions have been taken so far.

It should be emphasized that the Common Security and Defense Policy is voluntary cooperation, not only of countries belonging to the European Union but also of entities related to it through institutional ties of an intergovernmental nature. It is not a community policy but rather a combined approach based on agreements between individual governments. The Common Security and Defense Policy focuses on activities for security beyond the EU's external borders, and the defense of the Member States is a fundamental duty of each state and an allied commitment within the North Atlantic Alliance.

In the case of Poland, membership in the European Union is, along with membership in the North Atlantic Alliance, a key determinant of Polish security policy, or at least such 
statements can be found in subsequent documents on Polish priorities in this area. The central hypothesis adopted at the beginning of the research is the assumption that Poland has always treated security and defense within the European Union as a kind of complement to the potential and capabilities developed under the North Atlantic Alliance and that Polish involvement in the CSDP has never been adequate to the provisions contained in Polish political and strategic documents. Even a cursory analysis of Poland's activity under the CSDP confirms that it remained in the shadow of the North Atlantic Alliance almost from the beginning of Poland's strategic independence. Poland has never advocated full building autonomy in terms of security and defense within the EU. Relations with the United States and membership in NATO are the basic foundations of Polish security policy.

In this article, the authors will analyze Poland's experience resulting from our participation in the policy in question and the evolution of Poland's position toward its development in the context of Poland's security interests formulated in political and strategic documents.

\section{Poland's Strategic Independence after 1989}

Poland was in a difficult situation after 1989. On the one hand, it became a free and sovereign State. On the other hand, the Polish State had to quickly define itself in terms of foreign and security policy priorities and make up for the backwardness of independent thinking in these areas.

At the beginning of the 1990s, a procedure for national strategic defense planning and programming was initiated. Following it, the Political-Strategic Directive of the Republic of Poland and the resulting Plan of Defense of the Republic of Poland and Programme of Non-Military Defense Preparations of the Republic of Poland (Koziej, 2012, p. 20) were adopted, corresponding to the conditions of strategic independence.

The first document which defined general directions of defense policy, in which the internal and external conditions of Poland were discussed openly and generally for the first time, was the 'Defense Doctrine of the Republic of Poland' adopted by a Resolution of the Defense Committee of the Republic of Poland of February 21, 1990, on the Defense doctrine of the Republic of Poland (Monitor Polski, 1990; Marszałek-Kawa \& Plecka, 2015).

In the document, already in its initial part, provisions mention a close relationship between Poland's fate and the situation in Europe. Furthermore, it mentions that Poland recognizes the close link between national security and international security. It is, therefore, necessary to participate in and influence transnational processes, particularly those taking place in Europe or affecting it. The Doctrine states that Poland's security is based on alliances (bilateral and multilateral) and membership in the Warsaw Pact (which was disbanded on July 1, 1991), but at the same time, there is an announcement of change as the pan-European security system develops. It is worth noting that the Doctrine does not include the European Community, the Western European Union, or the North Atlantic Alliance as security and Defense policy objectives. Moreover, it is not in Poland's interest to maintain armed forces 
outside Poland. However, at the same time, it is announced that the Polish Army will continue to participate in international peacekeeping missions, especially under the aegis of the United Nations (UN) (Polacy w misjach pokojowych ONZ). This document is still in the shadow of the collapse of the Warsaw Pact. It can therefore be concluded that, in a sense, this was an announcement of upcoming changes. Still, it was also an expression of uncertainty and some confusion in the security environment at the time. Another stage in thinking about security and defense in Poland was adoption at the Defense Committee meeting on November 2, 1992, of the Assumptions of the Polish Security Policy and Security Policy and Defense Strategy of the Republic of Poland. The document was created due to more than a year's work by a dedicated team appointed for this purpose and was signed by the then President of the Republic of Poland, Lech Wałęsa. It laid down the basic principles of Poland's internal and external security and consisted of two parts, i.e., the Assumptions of the Polish Security Policy and the part devoted to the Republic of Poland's defense policy and defense strategy. In the introduction, the document's authors use the concept of defense strategy and doctrine interchangeably, making it possible to note that security was primarily equated with defense. The part devoted to the Polish security policy's principles already includes a provision on Poland's future membership in the European Communities and then in the EU.

Nevertheless, relations with the communities were de facto intended to facilitate Poland's accession to the North Atlantic Alliance. It is confirmed by Poland's position at the beginning of the 1990s, according to which 'The North Atlantic Alliance remains a key factor in political stability and peace in Europe; Poland particularly appreciates the Euro-Atlantic nature of this alliance and advocates the presence of US troops on our continent. Poland's strategic objective in the 1990s is membership in NATO and the Western European Union (WEU) as a European pillar of NATO and an important factor in the European collective security system' (Assumptions of the Polish security policy and Security Policy and Defense Strategy of the Republic of Poland, 1992, p. 5).

Therefore, it can be concluded that the Western European Union has not been treated as an alternative to NATO from the outset.

According to Zięba, the 'experience of the interwar period shows that alliance links with France and the United Kingdom did not constitute effective guarantees of Poland's security' (Zięba, 2005, p. 103). Membership in the Communities and then in the EU was supposed to ensure Poland's political stability and economic development. The 'Security Policy and Defense Strategy of the Republic of Poland' states that 'striving to connect with the European Communities creates the greatest hope for Poland to consolidate its independent state, democracy, and successful economic development. It is a geostrategic direction of political and economic rapprochement and Poland's participation in an effective Western collective security system' (Assumptions of the Polish security policy and Security Policy and Defense Strategy of the Republic of Poland, 1992, p. 8). It means that Poland's participation in the European Communities was treated primarily as an opportunity for economic development and consolidation of democratic solutions and adopted standards. It should be 
noted that, in the context of economic growth outside the European Communities, there was no alternative to Polish foreign policy; as regards ensuring Poland's security, other concepts were also formulated aimed at not deteriorating relations with Russia. An example of such a concept was the position of left-wing circles in the early 1990s, according to which the time of military alliances has irreversibly passed. Although the Alliance of the Democratic Left (SLD) 'did not deny the need for rapprochement with the West, it criticized the intention to join NATO (...). It was in favor of maintaining security as an objective of Polish policy and building a collective security system, preferring NATO's subordinate role toward CSCE' (Grodzki, 2009, p. 181). As the then SLD expert on international affairs pointed out, 'our country should be in favor of developing a new collective security system in Europe, and NATO could become a CSCE body' (Grodzki, 2009, p. 181).

Another idea put forward at the beginning of the 1990s by President Lech Wałęsa was creating an international military agreement in Central and Eastern Europe - the 'NATO-bis' and an economic organization - the 'EEC-bis'. Lech Wałęsa's concept was formulated without consulting the Ministry of Foreign Affairs. Nevertheless, it is difficult to conclude that the concepts had real chances of being implemented. Perhaps that is why Zięba said that 'due to the geopolitical situation between a united Germany and Russia, which is returning to the international arena, many often complained about the emerging "grey area" or "security void". However, no ideas were formulated about how to fill this void other than joining Western and Euro-Atlantic institutions' (Zięba, 2010, p. 81).

In the Treaty on the European Union establishing a de facto European Union (signed on February 7, 1992, thus a few months before the signature by the President of the Republic of Poland of the Assumptions of the Polish Security Policy and Defense Strategy of the Republic of Poland) in part devoted to the objectives of the EU, Article B provides that the European Union sets itself the objective to assert its identity on the international scene, in particular through the implementation of a common foreign and security policy, including the eventual framing of a common defense policy, which might in time lead to a common defense' (Treaty on European Union, Article B).

The section on the Common Foreign and Security Policy (CFSP) of the Treaty clarifies how and under what conditions it should be implemented.

Therefore, it can be concluded that the "EU Member States unanimously agreed that such a (political) union could not be based solely on an integrated economic and monetary area and an internal market' (Federal Foreign Office, n.d.). At that stage, however, Poland did not recognize the opportunity associated with the development of the (CFSP); it was instead in favor of 'building a system of collective security that would include Europe and North America' (Assumptions of the Polish security policy and Security Policy and Defense Strategy of the Republic of Poland, 1992, p. 10).

In this context, the EU is regarded as an element facilitating the achievement of a critical objective from Poland's point of view, namely Poland's membership in the North Atlantic Alliance. 
The Polish security policy's strategic objective was achieved in 1999 when Poland became a North Atlantic Alliance member. From the point of view of Polish security interests, this objective's achievement was fundamental and fulfilled both the authorities' and the public's expectations regarding moving closer to a united Western Europe. This time, membership in the political and military alliance was Poland's conscious choice, and obtaining security guarantees from the allies became the basis of the Polish security policy.

At the time of accession to NATO, Poland had already been in the integration process with the EU for five years, which began on April 8, 1994, when Prime Minister Waldemar Pawlak applied to have the Republic of Poland joining the EU. In 1989, the Agreement on Trade and Commercial and Economic Cooperation between Poland and EEC was signed. The Agreement's main objective was to create favorable conditions for the harmonious development and diversification of trade flows and promote trade and economic cooperation (Agreement between the Polish People's Republic and the European Economic Community on Trade and Commercial and Economic Cooperation, 1989). Then, at the beginning of the 1990s, further steps were taken to integrate with the European Community due to political changes in Europe and Poland. An official request was made for the opening of accession negotiations (May 25, 1990). In late 1991, the Association Agreement with the European Community and its Member States was signed. The Agreement concerned mainly issues related to the approximation and adaptation of the Polish economy to European Community requirements.

It was a milestone in the process of Poland's integration into the EU. Economic and social issues were the primary motivator of the actions taken toward integrating Poland into the European Community. However, already at that stage, some politicians saw the importance of the future EU and its political potential, including Poland and the region's security. At the time, Skubiszewski, Minister of Foreign Affairs, pointed out that 'when discussing relations with the EU, we are primarily talking about - and rightly so - economic matters. However, let us remember that the matter's essence lies in the political sphere because it concerns our broadly understood security. (...) It entails providing our country with a permanent and definitive place in Europe. (...) participation in the European Union will provide the other Member States and us with a guarantee not only of social and economic development but also the preservation and radiance of our existence' (Kuźniar, 2011, p. 509). However, the political elite's prevailing view was that the North Atlantic Organization should be the guarantor of Poland's security, first and foremost because the United States participates in it and that security issues in the context of the EU (or the WEU) should be considered only insofar as they would serve the purpose of Poland's quicker accession to NATO. The Western European Union (WEU) was seen primarily as a European pillar of NATO. However, at the beginning of the 1990s, there was no clear answer to whether Poland's accession to the North Atlantic Alliance would be possible. Also, NATO itself has held discussions on the legitimacy of the Alliance's survival given the cessation of the main prerequisite for its existence, i.e., the Warsaw Pact collapse. The Warsaw Pact was formally disbanded on July 1, 1991. Some 
experts predicted the imminent collapse of NATO due to the absence of a dominant external threat, but these expectations turned out to be at least premature. Instead of receding into the background, NATO flourished in the 1990s, at least in some respects' (Duffield, 2012, p. 298). Nevertheless, the prospect of Poland joining the Alliance was quite vague; therefore, the government of T. Mazowiecki sought other possibilities of obtaining security guarantees. In March 1990, Poland established cooperation with the Western European Union by posting Minister of Foreign Affairs K. Skubiszewski to participate in the extraordinary session of the WEU Assembly in Luxembourg. Poland subsequently became part of the WEU Consultative Forum in June 1992. Since its accession to NATO in 1999, Poland, together with Hungary and the Czech Republic, acquired the status of an associated member of the WEU. From the outset, the prospect of membership in the WEU was seen as easier to achieve, but it was not an end in itself, instead merely a means to achieve another objective, namely accession to NATO. As Węglarczyk said, 'since the beginning of the 1990s, our diplomats recognized that the WEU could be used as a side door to NATO membership. Everything at that time indicated that the efforts to join the Alliance would be very long and complicated (and were), and due to its minor importance, the WEU was therefore recognized by our Ministry of Foreign Affairs as easier to gain' (Węglarczyk, 2010). According to Zięba (2010, p. 82), 'Warsaw skeptically referred to the possibility of finding support in the Western European security structure, which would be deprived of the political and military presence of the US' It resulted from historical experience, especially in the interwar period, and doubts about France and the United Kingdom's security guarantees. It is worth noting, however, that it was initially in the Brussels Treaty and then in the 1954 Paris Agreements (de facto this is the date of establishment of the WEU) that a provision was made imposing on the Member States an 'obligation to provide unconditional assistance by any means at their disposal - military and other' in the event of an armed attack on any one of them. The scope of the aid is thus much more significant than in the North Atlantic Alliance's case (Karpiński \& Mikliszański, 2006,p. 7). When analyzing the Polish security policy over the years after the break-up of the Warsaw Pact, it can be concluded that the lack of provisions concerning the obligatory use of the armed forces in the event of the need to provide allied support within NATO is in a certain sense omitted. From Poland's entry into the Alliance, it is assumed that the Member States' assistance will send allied reinforcement forces in the case of external armed aggression. In Article 5 of the Washington Treaty, the lack of provisions on the mandatory use of the armed forces in case of the need to assist an ally is one of NATO's most significant weaknesses. Suppose the North Atlantic Council decides to activate Article 5 of the Washington Treaty. In that case, each Member State would need to make an individual decision on how to implement its alliance obligations under this Article. It is worth mentioning here that, in the case of the European Union, there is also a commitment to mutual assistance, the so-called 'mutual defense clause', according to which, where any Member State becomes the victim of armed aggression in its territory, the other Member States are obliged to provide assistance and support by any means available to them, per Article 51 of the Charter of the 
United Nations. It does not affect the specific nature of the security and defense policies of certain Member States (Treaty on the European Union, art. 42).

Since, as with the Washington Treaty, the Article does not impose an obligation to provide military assistance, no formal procedure has been established, and the EU is merely a coordinator. However, this provision is important in the EU Member States' security policy and non-members of the North Atlantic Alliance, such as Sweden or Finland.

Furthermore, it should be noted that the inclusion of a mutual defense clause in the Treaty of Lisbon is a crucial element in building the EU's strategic identity. It proves that EU leaders see that 'stronger and more efficient European defense is essential to consolidate the transatlantic relationship in the face of structural geostrategic changes accelerated by the global economic crisis, especially when the US's strategic position toward the Asian and Pacific region is changing' (European Parliament resolution, 22.11.2012).

As a member of the EU, Poland may also use the mutual defense clause, if necessary. It is undoubtedly part of Poland's security policy, which is often overlooked in the broad debate on Poland's security. Perhaps this is due to the traditionally skeptical approach to $\mathrm{EU}$ issues and perhaps often to the lack of knowledge and complexity of the EU reality.

\section{Security and Defense in the EU as Part of Poland's National Security Strategies}

Admittedly, in the Republic of Poland's first National Security Strategy adopted in 2000, the European Union is mentioned next to the North Atlantic Alliance. However, as Koziej pointed out in the document, 'NATO is the main factor in political and military stability on the European continent and Poland's factual basis for security and defense. Poland's second international security pillar was recognized as integration into the European Union', but above all in the context of participation in the Union's system of cooperation with NATO. It is evidenced by the statement made by Minister of Foreign Affairs W. Bartoszewski, who stated in 2001 in the Committee on Foreign Affairs that 'as regards our main tasks related to ensuring the security of our country, they are related to further strengthening our position in NATO structures while participating in the construction of the European Security and Defense Policy. We should naturally impact the development of ESDP political and military structures on the EU's links with NATO, but cooperation with NATO must be a strategic priority. It is due to NATO's role as a guarantor of stability and security in Europe and the Euro-Atlantic region. It is worth remembering that the Pact has adequate, tried structures and adequate military means, while ESDP is only in the process of shaping and discussing what forces it can put at its disposal. It is worth adding, perhaps perversely, that one should also take into account that Poland is already a member of NATO but not yet a member of the EU. In the first case, then, we have something to say, and we can decide on the future of the Pact and, in the second case, it will only prove what our participation in decision-making will be' (Foreign Affairs Committee, 2001). 
The statement perfectly reflects the Polish perception of EU security and defense issues at the beginning of the first decade of the $21^{\text {st }}$ century. Poland, not yet a member of the EU, has realized that integration with this organization and a multifaceted link between Poland and other European countries is necessary; it can be then concluded that this was a priority of the then Polish foreign policy, but was integration with the EU also a priority in the area of security policy? It would undoubtedly be a considerable burden to engage equally in the North Atlantic Alliance and the EU in security and defense. In 1999, Poland became a full NATO member; interestingly, the EU proclaimed the European Security and Defense Policy in the same year. In the following year, already under NATO membership conditions, the national security strategy was adopted, with another one coming three years later.

The 2003 National Security Strategy devotes a great deal of attention to the EU while drawing attention to the need for good cooperation with NATO. The transatlantic and European dimensions of the strategy are complemented by the intention to strengthen the UN and develop activities on non-European issues and bilateral cooperation in the region' (Koziej \& Brzozowski, 2015, p. 32).

Another document adopted in 2003 was correlated with the European Security Strategy adopted in the same year and the NATO Strategic Concept. It states that 'Membership in the European Union determines Poland's security basis to a significant extent. It radically increased possibilities for implementing Polish security policy and international impact capacity (...). The Polish authorities should advocate deepening integration processes in the European Union while preserving its members' unity and solidarity (...). It makes a significant contribution to the development of the EU's military and civilian crisis response capabilities. There will be a gradual increase in the commitment to creating a European rapid response force, including participation in the formation of battle groups. It will strive to meet the other objectives set forth by the European Operational Objective 2010. Poland will also make significant personnel and material contribution to stabilization, peace, humanitarian, rescue, and training missions organized by the European Union' (Szwed, 2007).

Does the question arise about what the document's authors understood as a 'significant personnel and material contribution?'Notwithstanding, it is worth noting that the excerpts mentioned above from the document are a relatively specific obligation on Poland. In the Security Strategy of 2014, the level of generality of the CSDP provisions is far more significant. It is difficult to find precise formulations regarding Poland's involvement in this policy. An example of this is the words: 'The European Union and the Common Security and Defense Policy (CSDP) developed within it will be an important security factor for Poland (...). The actions of the Polish State will be aimed at deepening the EU's integration processes in the field of security so that it has adequate security, including Defense capabilities' (Strategia bezpieczeństwa narodowego Rzeczypospolitej Polskiej, 2014).

To sum up, it should be noted that the practical dimension of polish involvement in the CSDP did not reflect the provisions contained in the political and strategic documents. At the declarative level, Poland supported and continues to strengthen the EU's security and 
defense policy. Still, the separated forces and resources for its needs are the minimum level necessary to maintain partner status, though with minimal influence.

\section{Building EU Military Capabilities and Poland's Approach}

The Helsinki European Council decided that by 2003 the EU would be able to deploy within 60 days and sustain for at least a year a force of up to 50,000-60,000 personnel, capable of performing the full spectrum of Petersberg Tasks. Also, decisions have been taken to establish new political and military bodies and structures, establish a non-military crisis management mechanism, and establish the principles under which non-EU countries will engage in the EU's European Security Defense Policy (Presidency conclusions, 1999).

Poland sought opportunities to engage in current initiatives. 'In 2000, the Minister of National Defense declared the Polish contribution to peacekeeping missions, thus confirming the Polish commitment to implementing the European Headline Goal. Poland certainly could not demand a larger share in developing the Common European Security and Defense policy without putting forward some concrete obligations in capabilities. In November 2001, Deputy Minister Janusz Zemke renewed the pledge of Polish contribution, this time better adjusting it to the EU's expectations. The minister also expressed Poland's willingness to support the European Capabilities Action Plan framework's efforts. However, the EU showed a lack of will to cooperate with third states, despite the original concept envisaging such a possibility' (Poland Country Study Guide Volume 1, p. 106).

Moreover, the 2002 NATO Summit in Prague announced the initiative to create NATO Response Forces, approved in Brussels in 2003. In the words of General James Jones, the then NATO Supreme Allied Commander Europe, ‘... NATO will no longer have the large, massed units that were necessary for the Cold War, but will have agile and capable forces at Graduated Readiness levels that will better prepare the Alliance to meet any threat that it is likely to face in this $21^{\text {st }}$ century' (NATO Response Force, 2020).

These decisions had an impact on Poland's involvement in ESDP. 'Poland's attitude about creating EU military capability was very reserved given its Atlanticist policy, which Warsaw manifested in its concern for NATO and zealous care for the US's interests. The Polish government was also engaged in creating the NATO Response Force. In a situation where NATO and the EU had decided to create similarly, and thus rather competing, armed forces for the same type of crisis reaction operations, Poland decidedly favored the NATO Concept, which it had even co-initiated' (Zięba, 2020, p. 147).

At the following planning conferences, the EU States declared their capacities for the European Headline Goal's needs. The Polish side expressed its contribution in the form of a framework brigade (two battalions) of 1,500 soldiers to carry out the Petersberg Tasks, as well as an aviation search and rescue group, an air-transport unit (three planes, of which one is a transport aircraft), a mine-sweeper, a rescue vessel, and a military gendarmerie unit (Zięba, 2020, p. 147). 
Nevertheless, the Polish side stipulated that the same forces had been reserved for NATO operations. Therefore, a decision on possible involvement will be taken whenever an EU operation is initiated. Despite the declarations made by the many Member States, the EU military capability-building programme called the European Operational/Fundamental Objective... de facto has not been completed. While excess declarations (e.g., over 100,000 soldiers, over 400 combat aircraft, 100 ships) have emerged in certain areas, there have been significant shortages in others (e.g., strategic and tactical air transport). In 2001, the planning conference identified 42 capacity gaps, of which 24 were identified as significant and assumed to be addressed by 2003 . As early as 2002, it became clear that the pace of work has decreased significantly, mainly due to the negotiations on the Berlin-Plus Agreement (Cooperation Agreement between the EU and NATO, 2003) and the preparations for the European Union military operation in the former Yugoslav Republic of Macedonia (The European Security and Defense Policy: from the Helsinki Headline Goal to the EU Battlegroups, Directorate-General for the Union's external policies, Directorate B). The EU military operation in the former Yugoslav Republic of Macedonia (CONCORDIA) was the first EU military mission - taken over from NATO and carried out by the EU Member States themselves. CONCORDIA was established on March 31,2003, at the request of Macedonian President Boris Trajkovski. It took over the tasks of Allied Harmony NATO forces (Musioł, 2007).

It is worth noting that the Berlin Plus agreement mentioned above, in fact, enabled the EU to conduct its first operations. Access to NATO's resources and capabilities was a milestone in developing the EU's capabilities and succeeding in the CONCORDIA or ALTHEA operations. However, it is worth mentioning that although this agreement is still in force, as S. Johnston notes, 'Indeed those who have heard of them tend to regard the idea as defunct because of the political impasse that has prevented it working' (Johnston, 2016). He also notes that the main problem relates to political issues and points at, among others, France, which has always opted for CSDP autonomy, the United Kingdom, which has sought to weaken the CSDP and at the same time strengthen transatlantic ties, or the political impasse between Turkey and Cyprus.

In 2003, the European Union adopted for the first time a security strategy called 'A Secure Europe in a Better World', and, in 2004, a military operation called Artemis was carried out in the province of Ituri in the Democratic Republic of Congo. The operation was successful and inspired the further development of EU military capabilities. The model of the solutions adopted for the Artemis operation was used to initiate the subsequent unveiling of the European Headline Goal 2010. The fundamental assumption was the creation of EU Combat Groups (EU CG). This rapid response force could be used in a crisis of EU operational interest and capable of carrying out a full range of crisis management tasks. It was assumed that by setting up the EU CGs by 2010, the EU would respond quickly and decisively to emerging crises. The EU's ambition is to decide to launch the operation within five days of the crisis response concept's approval and then initiate action in the operation 
area within ten days of the decision (Headline Goal 2010 approved by the General Affairs and External Relations Council on May 17, 2004, endorsed by the European Council of June 17-18, 2004).

The complex concept of the EU Combat Groups was presented in February 2004, and Poland became an EU Member State in May of the same year. Since the beginning, Poland has been an active participant in the idea of creating EU Combat Groups, which was based on the following premises:

1. A willingness to demonstrate in practice that participation in the Common Security and Defense Policy has become the third key pillar of Poland's security and contribution to the development of the CSDP after NATO membership and special relations with the US.

2. Treating the EU Combat Groups as the second, after NATO response forces, level of transformation of the Republic of Poland's armed forces, building their capacity to act in a global framework and developing their interoperability with the Member States' EU forces NATO.

3. Willingness to demonstrate the real possibilities for harmonizing the requirements and preparation process of the EU Combat Groups and NATO rapid response forces (first NATO Response Forces and after 2014 - NATO High Readiness Forces) (Experience and lessons learned from the preparation of the European Union Operations Command for the Visegrad Battle Group, p. 11).

So far, the Polish Army has several times separated forces and funds for the needs of the EU CG, i.e.:

- Multinational Combat Group in 2010

- Weimar Combat Group in 2013

- Visegrad Combat Group in 2016

- Visegrad Combat Group (+Croatia) in 2019

Besides, an OHQ (Operational Headquarters) was established for the EU CG in 2015 based on the Centre for Land Operations - Command of the Load Component in Cracow. 'Poland, therefore, joins the elite group of five countries which have command at such a level' (Nowe dowództwo UE jest w Krakowie, 2015).

It is a practical expression of Poland's implementation of the provisions of the Treaty on European Union, namely Article 42 (3), according to which the 'Member States shall, for the implementation of the common security and defense policy, make their civilian and military capabilities available to the European Union to contribute to the achievement of the objectives set by the Council. The Member States jointly establishing multinational forces may also make them available for the needs of the common security and defense policy' (Treaty on European Union, art. 42).

Polish involvement in the initiative of the EU Combat Groups can be assessed as significant. Still, it can also be concluded that the Polish authorities, like the British authorities, are convinced that the EU CG will not be used. In the UK case, this conviction was so firm 
that the 'UK Ministry of Defense acknowledged that no appropriations for the use of the Combat Groups had been budgeted since 2010' (Santo, 2016, p. 8).

Another element of Poland's CSDP activities is participation in military missions and operations under the EU's auspices. According to the information available on the website of the Ministry of National Defense, Poland is currently involved in 3 military operations, namely:

- EUFOR ALTHEA (Bosnia and Herzegovina),

- EUTM RCA, (Central African Republic),

- EUNAVFOR MED IRINI (EU Naval Force Mediterranean).

The first mission under the auspices of the EU involving the Polish military contingent was the CONCORDIA operation in the former Yugoslav Republic of Macedonia, and then, among others:

- EU Monitoring Mission (EUMM) in Georgia,

- EUTM Mali (Training Mission, Mali),

- EUFOR RD Congo (Congo RDC),

- EUFOR TCHAD/RCA (Chad-Central African Republic),

- EUFOR RCA (Central African Republic),

- EUTM RCA (Central African Republic, Africa),

- EUNAVFOR Atlanta (only liaison officers).

Is Poland's commitment to EU missions and operations sufficient? In light of the available data, it is certainly not evenly distributed, as 'between 1989 and 2009, Poland has assigned 67,000 soldiers and military personnel to participate in 64 missions and operations, including 30 UN missions, 13 alliance missions, 9 OSCE observation missions, six international coalition missions, and $6 \mathrm{EU}$ missions and operations' (MoND, Missions).

Poland's engagement in missions and operations under the auspices of the EU can be assessed as high. As Terlikowski notes, "Given Poland's limited military capacity (at least compared to the top European military powers) and involvement in numerous NATO operations, the Polish contribution to CSDP has to be assessed as relatively high" (Terlikowski, 2018). Similar observations can be found on the website of the Polish Ministry of Defense.

However, they can also be seen as minor. According to Przybylska-Maszner, "due to Poland's potential, the military operational engagement in Africa to date is limited. Except for the operations in the Democratic Republic of the Congo - EUFOR RD Congo (130 soldiers) and the operations in Chad and the Central African Republic - EUFOR Tchad/RCA (400 soldiers), Poland's participation in the operations as mentioned was symbolic".

According to the authors, Polish engagement in EU missions and operations should be assessed concerning countries with comparable potential. For this article, a comparison of Poland and Spain in the aspect in question was made (Przybylska-Maszner, 2016).

It can be said that Poland has been, and is, quite an active player in international military actions. Nonetheless, indeed, when considering engagement with the EU, there are things to be desired. By comparison, Spain, a member of both NATO and the EU, is a leading player in 
activities under the EU's auspices. Until 2008 Spain has participated in all 11 EU Operations (Sabiote, 2008). Seven hundred and sixty-seven (767) Spanish soldiers were involved in CSDP operations in 2017 (Mejía, 2017). As a maritime nation, Spain plays a crucial role in two CSDP military missions at sea: EUNAVFOR Atlanta and EUNAVFORMED Sophia. Spain also participates in four other military operations: EUTM Mali, EUTM RCA, EUTM Somalia, and EUFOR Althea and civilian operations: EUPOL COPPS, EUAM Ukraine, EUBAM Libya, EUCAP Sahel Niger, and EUCAP Sahel Mali (Mejía, 2017).

Table 1: Basic data on the defense of Poland and Spain

\begin{tabular}{lll}
\hline & Poland & Spain \\
\hline Population & 37.7 million & 46.4 million \\
\hline $\begin{array}{l}\text { Place in ranking } \\
\text { Global Firepower }\end{array}$ & $\begin{array}{l}21 \\
\left(6^{\text {th }} \text { in the EU }\right)\end{array}$ & $\begin{array}{l}20 \\
\left(5^{\text {th }} \text { in the EU }\right)\end{array}$ \\
\hline $\begin{array}{l}\text { Index value } \\
\text { Global Firepower (2020) }\end{array}$ & 0.3388 & 0.3397 \\
\hline $\begin{array}{l}\text { Defense expenditure } \\
\text { (\% GDP; CIA World Factbook 2019) }\end{array}$ & 2 & 0.92 \\
\hline $\begin{array}{l}\text { GDP per capita (thousands of euros) } \\
\text { Defense budget (in billions of dollars) }\end{array}$ & 12950 & 25150 \\
\hline $\begin{array}{l}\text { Number of armed personnel (in thousands; Global Fire- } \\
\text { power 2020) }\end{array}$ & 12 & 118.1 \\
\hline
\end{tabular}

Source: Own study.

Spain is undoubtedly a country that strongly supports the CSDP, both politically and in practice. Quoting the provisions of the Spanish National Security Strategy' A shared project, by all and for all' from 2017, 'in addition to defending its national interests, Spain wants to play a greater leadership role in building an effective, more integrated, and more democratically justified EU - an EU with the possibility of responding to the situations set out in the European Union's Global Strategy for Foreign Affairs and Security' (National Security Strategy, 2017, p. 41).

As the only country, it has been involved in all EU military operations and has declared its strong support from the outset for CSDP strengthening activities, including Permanent Structural Cooperation.

Therefore, both Poland and Spain support the development of CSDP at the declarative level, declare their willingness to participate in this process. Still, in practical terms, it is not easy to assess polish contribution as significant, especially compared to Spain.

The Polish involvement in the maritime dimension is abysmal. Since 2008, the European Union has conducted the first naval military operation off the Somali coast. Britz (2016, p. 189) stated that most of the EU's large states have engaged in Atlanta - Sweden, the United Kingdom, Germany, Greece, Italy, Spain, France, and Norway (non-EU) have allocated vessels. Moreover, even Romania, the poorest country in the EU, has made an effort to commission 
a Type 22 F221 Regele Ferdinand missile frigate. We, on the other hand, deployed only a small number of liaison officers. The justification of non-participation of the Polish navy in the EU NAVFOR ATALANTA operation was related to the lack of its connection with the Defense of the country's territory, as well as the limited resources of the Polish Armed Forces, which, as it was stated, should be used for other purposes (i.e., the defense of Polish territory).

Another EU military naval operation is the EU NAVFOR Med. IRINI. So far, 24 countries have committed to the operation, with ships and helicopters assigned to the operation. Poland is engaged in these operations based on the decision on the 'decision on the participation of the Polish Military Contingent in the new EUNAVFOR MED IRINI operation, in which up to 120 soldiers and employees will take part, as well as the M28B 1R BRYZA patrol and reconnaissance aircraft from BLMW' (Polski Kontyngent Wojskowy IRINI w ramach EUNAVFOR MED IRINI).

It should be stressed that the decision to engage in the operation is the first significant contribution of the Polish Navy to EU military activities, albeit without the participation of vessels.

\section{Producer or Consumer of Security as Part of the CSDP? - The Evolution of Poland's Approach in Recent Years}

Poland's approach to security and defense matters in the EU is a consequence of broader processes related to the perception of its membership in the EU and of the European Union itself. Poland's perception of these issues is subject to some fluctuations, depending on the international environment's situation, within the EU, and depending on the country's social mood. Indeed, the efficiency and effectiveness of the EU in dealing with crucial security issues is an essential factor in shaping its image as a security producer and consumer.

Since the launch of the ESDP, Poland has expressed concerns about the duplication of capabilities and possibilities of the North Atlantic Alliance. The breakthrough came in 2007 when the 'new PO-PSL government decided to get involved in all European Union Matters' (Zięba, 2018, p. 457). In 2009, the Lisbon Treaty was adopted, which introduced changes in the ESDP, among others, by renaming to the Common Security and Defense Policy. In the same year, Poland launched an initiative to strengthen the EU's Defense. A specific package of proposals was presented to the head of France's diplomacy and contained several initiatives, from creating new units to infrastructure projects (Wojciechowski, 2009).

The result was the signing of a joint Polish-French declaration and a letter from the Ministers of Foreign Affairs of the Weimar Triangle to the High Representative for Foreign Affairs and Security Policy on strengthening the security and defense of the EU.'They wrote about the need to take steps to increase the European Union's potential. As stated in the letter, the Common Defense and Security Policy must become more cost-effective and, at the same time, more efficient. It is to be done in full complementarity with NATO; in particular, we should build on the partnership between the European Defense Agency and the NATO 
Allied Command Transformation. As Minister Sikorski pointed out at that time, it was not about creating bureaucratic structures but about increasing capacity, using battle groups, and materially increasing European security. The Treaty of Lisbon created the mechanism of such enhanced structured cooperation' (Łada, 2011).

It was particularly important given the Polish Presidency of the EU Council in 2011. In the presidency's programme, strengthening the CSDP has been identified as a priority.'The aim of Polish actions was, at that time, to revitalize the discussion on ways of increasing the effectiveness of the CSDP. The specific areas of our interest were: (1) increasing the usefulness of the Combat Groups; (2) strengthening the EU's capacity to plan and conduct military operations; (3) development of the Pooling and Sharing initiative, in coordination with NATO's Smart Defense initiative; and (4) deepening cooperation with partners, in particular, the EU's eastern neighbors and NATO' (MoND, European Union).

As a result, there has been a slight recovery in the CSDP area. The European External Action Service has been obliged to develop proposals to strengthen the Combat Groups' use. The Council Declaration on Joint Financing of Strategic Transport of Combat Groups 2012-2013 was adopted. The Council of the European Union also adopted a list of 11 Pooling and Sharing projects and decided to activate the Operations Centre for CSDP operations in the Horn of Africa (Polish Presidency of the Council of the European Union, Final Report, 2012, p. 169).

When analyzing the changes in Poland's approach to CSDP, it should be noted that the years 2007-2011, and in fact until 2015, were when Poland's support for this policy was evident. As L. Chappell points out, 'Poland's Presidency allowed it to become a fully-fledged leader' (Chappell, 2020, p. 217). In its deliberations, the author questions whether Poland can be a potential leader in the CSDP area and notes that the Polish State had transformed from a skeptical participant to a potential leader in 2013. She analyses Poland's strategic culture and points out that Atlanticism is one of its key elements. CSDP is essential, but instead in the context of regional security and its perception of security. As Sikorski highlights, 'the experiences of the Polish Presidency show us that the EU Common Security and Defense Policy is possible to implement in a group of 27 countries and that we must initiate tighter cooperation between willing countries, in line with the provisions of the Treaty of Lisbon' (Chappell, 2020, p. 218).

The decisive change in Poland's perception of the EU was brought about in 2015 when the EU faced the immigration crisis. It was undoubtedly a test that, at least in terms of solidarity, resulting from the system of values on which the $\mathrm{EU}$ is founded, but also per Article 80 of the Treaty on the Functioning of the EU - the European Union failed. In the same year, elections took place in Poland, in which the right-wing party Law and Justice (PiS) won. Although it supports Poland's membership in the EU and its programme, it also believes that the European Union needs a thorough reform. The PiS programme in 2014 very strongly emphasized the importance of national interests over community interests, as well as opposition to the federal direction of integration: 'The EU is - and must remain 
- an international organization; only and as much as - an international organization and therefore an association of sovereign, i.e., independent, states' (Programme of the Law and Justice Party, 2014, p. 151).

In the remainder of the programme, there are statements that 'Poland must be able to afford its own bilateral and multilateral foreign and security policy and set its objectives. Membership in international organizations, such as the European Union or the North Atlantic Alliance, should be treated as a tool for pursuing Polish national interests and for creating an international environment favorable to us in cooperation with other countries, rather than as an objective in itself and ending Polish self-determination' (Programme of the Law and Justice Party, 2014, p. 151).

In recent years, there has been a significant revival of the EU's security and Defense policy. According to J. Gotkowska, this was influenced by three key elements, i.e.:

- Brexit;

- Donald Trump's policy and requirements for European allies;

- Adoption by the European Council in June 2016 of the European Union's Global Strategy for Foreign and Security Policy (Gotkowska, 2017).

The undisputed leader in this area is France, which, especially in connection with Brexit, very quickly noticed and seized the opportunity to strengthen CSDP and, in the long term, to build an autonomous defense capability of EU countries (Gotkowska, 2019). Nevertheless, Paris' ambitious plans have been modified and, as a result, 'France has recognized that its ambitious proposals on the exclusivity and operational use of PESCO have been watered down. The EU focuses on creating new institutions and structures and not on the actual construction and operational use of military capabilities' (Gotkowska, 2019). In response, France has taken the initiative to create a European Intervention Initiative, a format for cooperation outside the EU and NATO. 'Poland has not yet been invited to do so. It is the result of Paris' observation that Warsaw puts strengthening NATO and participation in USled foreign operations above European cooperation, and would act as a brake on the whole process' (Gotkowska, 2019). Indeed, the French vision of Defense in Europe is controversial in many countries, especially those that the North Atlantic Alliance recognizes as the basis for its security policy. From the perspective of Polish interests, the French initiative may pose a threat, especially in further deepening the French-Russian rapprochement while reducing the United States' role.

Interestingly, the Brexit decision also influenced an intensification of efforts on the part of Spain, resulting in the relocation of the Operation Atlanta Command to Rota, Spain, except for the Maritime Security Centre for the Horn of Africa (MSCHOA), which is located in Brest, France, by Council Decision (CFSP) 2018/1083 of July 30, 2018. 'With Britain's naval power at the EU's exit door, Spain has gone on the offensive to be the next major player defending European shores' (EURACTIV.com and AFP, 2018).

Other European States' position on strengthening CSDP varies and depends on geopolitical conditions, threat perception, historical experience, and, more broadly, strategic culture. 
Since PiS took over power in Poland, there has been an evident change in policy direction toward the EU. It can be described as a shift from Euro-enthusiasm and a state aspiring to a leading position in Central and Eastern Europe to a Euro-sceptic state with a conservative and nationalist orientation. According to experts, the results of the 2019 European Parliament elections in Poland have shown that 'one can especially expect the continuation of the course, leading to a divergence (confrontation) toward the EU position on the response to the fundamental challenges, concerning:

- climate change (and its impact on energy policy),

- demographic change (and its impact on social and migration policies),

- building a common defense policy based on strengthening cooperation between arms industries,

- plans to prevent fragmentation of the EU by including all Member States with a temporary derogation in the euro zone' (Barcz et al., 2019).

Nevertheless, assurance can be found on the official website of the Ministry of National Defense in Poland that 'Poland is actively involved in military CSDP activities. We are participating in defense capacity development projects; we are releasing forces to the Combat Groups and participating in EU operations. We take part in projects in the area of Defense capabilities development, we assign forces to the Battle Groups and participate in EU operations. We also participate in works aimed at developing CSDP, including through optimal use of the instruments of the Lisbon Treaty' (MoND, European Union).

Key projects and initiatives under the CSDP in which Poland participates include:

- EU military and civilian missions and operations;

- EU Combat Groups;

- Permanent Structural Cooperation;

- Pooling and Sharing;

- Coordinated annual review of CARD defense;

- EDF's European Defense Fund.

It is worth noting that Poland actively participates in PESCO (Permanent Structured Cooperation) initiatives, i.e., projects aimed at deepening military cooperation of the EU Member States. Currently, there are 25 countries involved in PESCO. "An initial list of 17 projects to be developed under PESCO was adopted by the Council on 6 March 2018. The second batch of 17 projects to be developed under PESCO was adopted by the Council on 19 November 2018. Finally, the third batch of 13 additional projects to be developed under PESCO was adopted by the Council on 12 November 2019. One PESCO project from the first batch has been officially closed by its project members" (pesco.europa.eu).

'Poland is a participant in 12 PESCO projects and an observer in 12 more. Among the 12 projects in which Poland participates is also the Medical Training Centre for Special Forces (SMTC) project, initiated by the EU Council decision of November 2019, of which Poland is the coordinator.In addition to Poland, Hungary participates in the project, while the Czech Republic, France, Spain, Ireland, and Slovakia have an observer status' (MoND, European Union). 
Poland participates in the following projects:

- Military Mobility (Coordinator: Netherlands);

- European Secure Software-defined Radio - ESSOR (Coordinator: France);

- Network of Logistic Hubs in Europe and Support to Operations (Coordinator: Germany);

- Maritime Semi-Autonomous Mine Counter Measures - MAS MCM (Coordinator: Belgium);

- Harbor and Maritime Surveillance and Protection - HARMSPRO (Coordinator: Italy);

- Rapid Response Teams and Mutual Assistance in Cyber Security (Coordinator: Lithuania);

- EU Radionavigation Solution - EURAS (Coordinator: France);

- Integrated Unmanned Ground Systems - IUGS (Coordinator: Estonia);

- Integrated European Joint Training and Simulation Centre - EUROSIM (Coordinator: Hungary);

- European Medical Command (Coordinator: Germany);

- French EU Collaborative Warfare Capabilities - ECoWAR (Coordinator: France) (PESCO-Consilium, 2020).

Poland's position is open but at the same time conservative. As pointed out by M. Kaźmierski, the Polish side is making efforts 'to ensure that the priorities related to the development of defense and military capabilities within the EU countries, which in most cases belong to NATO, are not changed through the new mechanisms, but at the same time to seize the opportunities offered by these programmes for the development of those capabilities that can be used for collective defense and, as in the case of EDF, for the development, participation, and involvement of our defense industry' (Kaźmierski, 2018).

Poland, like the Baltic States, traditionally seeks hard guarantees of security. From this perspective, membership in the North Atlantic Alliance and the strategic partnership with the United States will be of key importance.

Therefore, from the point of view of Poland, priority is given to projects and initiatives which:

- could also be used for NATO collective defense purposes;

- take into account the Polish specificity of perceptions of threats;

- take into account the needs of the region of Central and Eastern Europe;

- will focus not only on southern Europe but also on the east;

- provide Poland and other countries in the region with equal access to financial resources earmarked for strengthening defense, including the development of the defense industry;

- will be aimed at developing capabilities needed to defend the territory, combat capabilities, and crisis response capabilities. 
In a way, this conflicts with France's interests, whose priority is to create a rather exclusive group of European States ready to engage more in defense and support the strengthening of crisis response and French intervention policy in Africa and the Middle East. The solutions adopted so far by the EU can be described as a compromise between France, Germany, and countries such as Poland.

It is worth mentioning that France, as a country that historically seeks allies on the European continent, after a series of terrorist attacks, activated the "mutual defense clause" resulting from Article 42 paragraph 7 of the Treaty on European Union. All EU states have expressed support for the French request for assistance. The position of the Polish government on this issue was voiced by the then Minister of National Defense A. Macierewicz, who stated that 'Poland fully respects and approves this position of France' (Polish Press Agency (PAP), 2015).

Assistance from the Polish side was declared, which was an important signal given the newly formed government and the uncertainty of its perception of its obligations under the EU treaties.

However, it should be mentioned that after Great Britain exited from the EU, Poland lost a rather significant ally. The positions of the United Kingdom and Poland in terms of CSDP converge on critical issues, as stated by A. Siemaszko: 'The United Kingdom remains one of the States that best understands the security dilemmas of its eastern allies, and is also involved in the Alliance's planned rotational military presence in the Baltic States (...)' (Siemaszko, n.d.). Like Poland, the United Kingdom is taking a firm stand against the sanctions imposed on the Russian Federation in connection with the annexation of Crimea.

\section{Conclusions}

The analyses carried out make it possible to ascertain that Poland's approach to developing CSDP evolved and was a derivative of many internal and external conditions.

Initially, in the 1990s, the involvement in the security and defense policy of the WEU/EU was treated primarily as a factor intended to speed up Poland's membership in NATO. Later, support was declared for the development of the ESDP, but at the same time, the priority of the North Atlantic Alliance and transatlantic relations was strongly emphasized. The period of the PO-PSL administration can be indicated as the time of Poland's increased involvement at this level; according to some experts, it was even a moment when Poland had the chance of becoming a leader.

The period of the Polish Presidency of the EU Council should be perceived as a time of initiating a discussion on the strengthening of the CSDP. From the perspective of several meetings and seminars that were organized, it can be concluded that it was a time when Poland, in a sense, took the initiative. At the same time, as it turned out, the skeptical attitude to these issues on the part of the representatives of many member states, and especially of 
UK Defense Secretary L. Fox, effectively prevented Poland from taking the initiative. Fox effectively stopped real progress in this matter.

The next few years are, above all, the time of the immigration crisis in Europe and, in Poland, the take-over of power by the right-wing and conservative party PiS. It is reflected in Poland's commitment to the CSDP, which is quite cautious and identifiable as Poland's 'auxiliary external pillar' (Zięba, 2018) of security. As Zięba points out, Warsaw's interest in strengthening the CSDP has fallen. The following elements demonstrate this:

- withdrawal from the commitment to be a framework state and a full member in Eurocorps;

- lack of commitment to the process of revitalizing the stagnant CSDP;

- difficulties and crises in cooperation with France and Germany (Zięba, 2018, pp. 460-461).

It should be mentioned that Poland's skeptical approach to CSDP has its source also in the weakness of the political framework and the lack of political consensus on the development of this policy among the member states. It is difficult and sometimes impossible to reach an agreement with twenty-seven different governments and autonomous decision-making centers. Differences in the perception of the role of the CSDP, the approach to challenges and threats to EU security, or NATO's role in the European security architecture are just some of the issues to which there is no consensus among EU leaders. Such conditions lead to a critical assessment of the possibility of achieving strategic autonomy within the EU.

In response to another research problem concerning the assessment of Poland's involvement in the CSDP in light of political and strategic documents, it is essential to point out a certain dissonance at this level. On the declarative level, in successive documents since the beginning of the 1990s, the EU has been mentioned as the second pillar of Polish security policy.

However, when analyzing Poland's practical actions in this respect, especially its involvement in EU missions and operations and other initiatives as part of this policy, it should be noted that it has been somewhat symbolic in many situations. It is particularly visible when compared with Spain, which has similar military potential and is also a member of the North Atlantic Alliance.

However, Poland's active attitude toward the CSDP during its presidency in the EU Council and its involvement in the EU Battle Groups initiative is worth highlighting. Polish experience from participation in these formations is of great importance. It was yet another opportunity (after the NATO Response Force) to transform the Polish Armed Forces and strengthen their interoperability and ability to operate within multinational structures. Combat tours in the years 2010, 2013, 2016, and 2019 and the creation of Operations Headquarters Command (OHQ) in Cracow confirm Polish involvement in the process of EU Battle Groups creation.

Another element that deserves attention is Poland's involvement in PESCO projects. It is an opportunity that Poland seizes to bridge existing gaps and shortfalls in its defense 
capabilities while pushing for broad access to the European Defense Fund (EDF) or the Defense Technological and Industrial Base (DTIB).

However, in the view of some commentators' political and personal considerations largely drive Polish leaders' skepticism of EU attempts to develop genuine defense cooperation. After months of criticizing the launch of PESCO and dithering, Warsaw became one of the last member states to signal its intention to join the initiative' (Zaborowski, 2018).

According to the authors, Poland should look for ways of diversifying security guarantees, especially when returning to nationalist narratives in many European countries.

It should be noted that Poland's perception of CSDP is not only an effect of the current situation, but has its source in Poland's historical experience, and above all, in the fears related to the proximity of the Russian Federation, as well as the 'labile' guarantees of the allied European States. In this context, it makes sense to look for hard security guarantees and initiatives that will support international cooperation on the one hand and strengthen Poland's defense capabilities on the other. Nevertheless, Poland must balance its commitment to the US's strategic partnership and efforts to remain integrated into the CSDP. The area that leaves much to be desired is the Polish commitment to creating maritime safety. Admittedly, it should be emphasized that the Polish Navy has currently allocated forces and resources for the EUNAVFOR Med. SOPHIA, except that they are still not ships. At this point, it is worth noting that Poland, like other EU countries, adopted the EU Maritime Safety Strategy in 2014 and is obliged to implement its provisions. The document states that maritime security is mainstreamed into the Common Foreign and Security Policy (CFSP).

It is reasonable to doubt whether Poland in this context will limit itself only to the role of participant and discussant at the common table or whether it will have the strength and resources to become an active and fully-fledged producer and creator of maritime safety in the EU dimension?

\section{References:}

Agreement between the Polish People's Republic and the European Economic Community on Trade and Commercial and Economic Cooperation, drawn up in Warsaw. (1998, September 16). http://prawo. sejm.gov.pl/isap.nsf/download.xsp/WDU19900380214/O/D19900214.pdf

Aleksandrowicz, T. (2011). Bezpieczeństwo w Unii Europejskiej. DIFIN.

Assumptions of the Polish security policy and Security Policy and Defence Strategy of the Republic of Poland, adopted by the National Defence Committee. (1992, November 2).http://koziej.pl/wp-content/ uploads/2015/07/Strategia_RP_z_92_r.doc

Barcz, J., Czachór, Z., \& Dyduch, J. (2019). The situation in Poland after the elections to the European Parliament. https://ec.europa.eu/poland/news/190624_wybory_pl

Biscop, S. (2017). Oratio pro PESCO. Egmont Paper, 91. http://www.egmontinstitute.be/publication_article/oratio-pro-pesco 
Biuro Spraw Międzynarodowych. (2006). Zgromadzenie Unii Zachodnioeuropejskiej i udział Polski w jego pracach 1999-2005. Biuletyn Informacyjny, 3(45). Wydawnictwo Sejmowe.

Britz, M. (2016). European Participation in International Operations. The Role of Strategic Culture. Palgrave Macmillan.

Chappell, L. (2017). Poland and the Common Security and Defense Policy: Potential Leader? Reviewing European Union Accession, Law in Eastern Europe, 67. https://brill.com/view/book/edcoll/9789004352070/B9789004352070_016.xml.p. 217.

CIA World Factbook. (2019). https://www.cia.gov/the-world-factbook

Civilian and military personnel in CSDP missions and operations, Policy Department, Directorate-General for External Policies. (2017). European Union, 2017.http://www.europarl.europa.eu/RegData/etudes/ STUD/2017/578035/EXPO_STU(2017)578035_EN.pdf

Cooperation Agreement between the EU and NATO on making available to the European Union, the military resources of the Alliance. Set of crucial cooperation documents agreed by both organizations. (2003, March 17). http://www.psz.pl/index.php/slownik/30-berlin-plus

Defence doctrine of the Republic of Poland, Resolution of the National Defence Committee of February 21, 1990, on Poland's Defence doctrine. (1990). Monitor Polski. http://koziej.pl/wp-content/ uploads/2015/07/Doktryna_obronna_RP_z_1990_r.doc

Duffield, K. (2012). Sojusze. In P.D. Williams (Ed.), Studia bezpieczeństwa. Uniwersytet Jagielloński.

EURACTIV.com and AFP. (2018). Spain's navy wants to play a significant role in post-Brexit European defence.https://www.euractiv.com/section/defence-and-security/news/spains-navy-wants-big-rolein-post-brexit-european-defence

European Commission, Launching the European Defence Fund, Communication from the Commission to the European Parliament, The Council, The European Economic and Social Committee and the Committee of the Regions. (2017). https://ec.europa.eu/docsroom/documents/23605

European Parliament resolution of November 22, 2012, on EU mutual defence and solidarity clauses: the political and operational dimension (2012/2223(INI)). https://eur-lex.europa.eu/legal-content/EN/ $\mathrm{TXT} /$ ?uri=CELEX\%3A52012IP0456

Eurostat figures. (2020).https://ec.europa.eu/eurostat/databrowser/view/sdg_08_10/default/table?lang=en Experience and lessons learned from the preparation of the European Union Operations Command for the Visegrad Battle Group duty (EU OHQ V4 - 2016/I). (2018).Dowództwo Operacyjne RSZ. COL-DKL im. Gen. Broni Władysława Andersa.

Federal Foreign Office. (n.d.) The development of the CFSP. https://www.auswaertiges-amt.de/en/ aussenpolitik/europa/aussenpolitik/gasp/geschichtegasp-node

Foreign Affairs Committee. (2001). http://orka.sejm.gov.pl/Biuletyn.nsf/0/6E809974F05A7ED1C1256B7 3003DE95A?OpenDocument

Global Firepower. (2020). https://www.globalfirepower.com

Gotkowska, J. (2017). Renesans wspólnej polityki bezpieczeństwa i obrony UE. Szanse i wyzwania dla wschodniej flanki. https://www.osw.waw.pl/pl/publikacje/komentarze-osw/2017-06-28/renesanswspolnej-polityki-bezpieczenstwa-i-obrony-ue-szanse-i

Gotkowska, J. (2019). European Intervention Initiative, i.e. the French idea to defend Europe. https:// klubjagiellonski.pl/2019/12/30/europejska-inicjatywa-interwencyjna-czyli-francuski-pomysl-naobrone-europy/\#

Grodzki, R. (2009). Polska polityka zagraniczna w XX i XXI wieku, główne kierunki-fakty-ludziewydarzenia.http://koziej.pl/wp-content/uploads/2015/07/Doktryna_obronna_RP_z_1990_r.doc

Headline Goal 2010 approved by the General Affairs and External Relations Council. (2004, May 17). The 
European Council of June 17-18, 2004. https://www.europarl.europa.eu/meetdocs/2004_2009/ documents/dv/sede110705headlinegoal2010_/sede110705headlinegoal2010_en.pdf

Heisbourg, F. (Ed.) (2000). European Defence: Making It Work. Chaillot Papers, 42. https://www.iss. europa.eu/sites/default/files/EUISSFiles/cp042e.pdf

Johnston, S. (2016). European Defence: Berlin Plus is still the answer.https://www.linkedin.com/pulse/ european-defence-berlin-plus-still-answer-sandy-johnston

Joint declaration by the President of the European Council, Donald Tusk, the President of the European Commission, Jean-Claude Juncker, and the Secretary General of NATO, Jens Stoltenberg. (2017). https:// www.consilium.europa.eu/pl/press/press-releases/2016/07/08/eu-nato-joint-declaration/

Juncker, J.C., \& Sobotka, B. (2017). Europe Must Take Its Defense into Its Own Hands. The Wall Street Journal.https://www.wsj.com/articles/europe-must-take-its-defense-into-its-own-hands-1496688441

Kaźmierski, M. (2018). Transcript of Committee Meeting on February 6, 2018. http://www.sejm.gov. pl/Sejm8.nsf/biuletyn.xsp?documentId=27080C7D5F10C728C1258232004FE0A0

Karpiński, M., \& Mikliszanski, K. (2006). Zgromadzenie Unii Zachodnioeuropejskiej i udziat Polski w jego pracach 1999-2005. Wydawnictwo Sejmowe. http://orka.sejm.gov.pl/opinie6.nsf/dok?Open Agent\&BSM_45

Koziej, S. (2012). Obronność Polski w warunkach samodzielności strategicznej lat 90. XX wieku. Bezpieczeństwo Narodowe, 21.

Koziej, S. (2011). Potrzeba nowelizacji strategii bezpieczeństwa Unii Europejskiej. Bezpieczeństwo Narodowe, 20.

Koziej, S., \& Brzozowski, A. (2015). Strategia bezpieczeństwa narodowego Rzeczypospolitej Polskiej 1990-2014. Refleksja na ćwierćwiecze. In R. Kupiecki (Ed.), Strategia bezpieczeństwa narodowego. Pierwsze 25 lat. Wojskowe Centrum Edukacji Obywatelskiej im. płk. dypl. Mariana Porwita. https:// koziej.pl/wp-content/uploads/2016/01/Strategie-bezpiecze\%C5\%84 ${ }^{\text {st }}$ wa-1990-2014.pdf

Kuźniar, R. (Ed.) (2011). Krzysztof Skubiszewski - dyplomata i mąż stanu. PISM.

Kuźniar, R. (2006). Polityka i siła. Wstęp do studiów strategicznych.

Kuźniar, R. (2014). Wzlot i upadek Europejskiej Polityki Bezpieczeństwa i Obrony. Bezpieczeństwo Narodowe, $I V$. https://en.bbn.gov.pl/ftp/dok/03/kuzniar.pdf.

Łada, A. (2011). Obrona na Prezydencje. https://www.isp.org.pl/pl/blog/obrona-na-prezydencje

Marszałek-Kawa, J., \& Plecka, D. (2015). Political culture and the democratisation of a political regime. The case of Poland after 1989. European Journal of Transformation Studies, 3(2), 24-40.

Mejía, A. (2017). Spain's contribution to Euro-Atlantic security. http://www.realinstitutoelcano.org/ wps/portal/rielcano_en/contenido?WCM_GLOBAL_CONTEXT=/elcano/elcano_es/zonas_es/ defensa+y+seguridad/ari60-2017-mejia-spain-contribution-euro-atlantic-security

Missions. Ministry of National Defence. https://www.gov.pl/web/national-defence/missions.

European Union. Ministry of National Defence-MoND. https://www.gov.pl/web/obrona-narodowa/ ue-unia-europejska

Musioł, M.(2007). Bezpośrednie zaangażowanie UE w utrzymanie pokoju w Europie. http://www.psz. $\mathrm{pl} / 168$-archiwum/marek-musiol-bezposrednie-zaangazowanie-ue-w-utrzymanie-pokoju-w-europie National Security Strategy. (2017). A shared project, by all and more significant. https://www.dsn.gob. es/sites/dsn/files/2017_Spanish_National_Security_Strategy_0.pdf

NATO Response Force. (2020). https://www.nato.int/cps/en/natolive/topics_49755.htm

PESCO-Consilium. https://www.consilium.europa.eu/media/46846/pesco-projects-20-nov-2020.pdf

PESCO member states driven. https://pesco.europa.eu

Polacy w misjach pokojowych ONZ.http://unic.un.org.pl/misje_pokojowe/polacy.php. 
Poland Country Study Guide Volume 1 Strategic Information and Developments. International Business Publications. https://books.google.pl/books?id=RmrdCwAAQBAJ\&printsec=frontcover\& $\mathrm{hl}=\mathrm{pl} \# \mathrm{v}=$ onepage $\& \mathrm{q} \& \mathrm{f}=$ false

Polska Agencja Prasowa. (2015). Francja aktywuje klauzule wzajemnej obrony Unii Europejskiej. https://www.pap.pl/aktualnosci/news\%2C432411\%2Cfrancja-aktywuje-\%0Aklauzule-wzajemnejobrony-\%0Aunii-europejskiej.html

Polski Kontyngent Wojskowy IRINI w ramach EUNAVFOR MED IRINI.https://www.wojsko-polskie. $\mathrm{pl} / \mathrm{pkw}$-eu-irini

Populationot.net. (2020). https://www.populationof.net/pl

Posen, B.R. (2006). European Union Security and Defense Policy: Response to Unipolarity? Security Studies, 15(2), 149-186. DOI: 10.1080/09636410600829356. https://doi.org/10.1080/09636410600829356

Presidency conclusions 10 and 11 December 1999. Helsinki European Council. https://www.europarl. europa.eu/summits/hel1_en.htm

Programme of the Law and Justice Party. (2014). http://pis.org.pl/dokumenty?page=2

Quille, G. (2006). The European Security and Defence Policy: from the Helsinki Headline Goal to the EU Battlegroups. Directorate-General for the Union's external policies, Directorate B. https:// www.europarl.europa.eu/meetdocs/2009_2014/documents/sede/dv/sede030909noteesdp_/sede030909noteesdp_en.pdf

Sabiote, A.M. (2008). Does Spain fit in the European Defence policy? Spain and EU crisis management operations. https://www.recercat.cat/bitstream/id/61444/12.pdf

Santo, M. (2016). Leaving the European Union: UK Armed Forces and Diplomatic Service. https:// lordslibrary.parliament.uk/research-briefings/lln-2016-0066/

Siemaszko, A. Brexit a bezpieczeństwo w Europie. Jaki wpływ na spójność Zachodu? https://www. defence24.pl/brexit-a-bezpieczenstwo-w-europie-jaki-wplyw-na-spojnosc-zachodu

Strategia bezpieczeństwa narodowego Rzeczypospolitej Polskiej. https://www.bbn.gov.pl/ftp/SBN\%20 RP.pdf

Szwed, J.(2007). Strategia bezpieczeństwa narodowego Rzeczypospolitej Polskiej. https://www.academia. edu/10567744/STRATEGIA_BEZPIECZE\%C5\%83STWA_NARODOWEGO_RZECZYPOSPOLITEJ_ POLSKIEJ

Tardy, T. (2017). MPCC: towards an EU military command? EUISS Brief, 17. http://www.iss.europa. eu/ publications/detail/article/mpcc-towards-an-eu-military-command

Terlikowski, M. (2017). Europejski Fundusz Obronny: wspar $\neg$ cie finansowe dla przemysłu obronnego UE. Komentarz PISM. http://www.pism.pl/publikacje/ko ᄀmentarz/nr-26-2017

The European Security and Defence Policy: from the Helsinki Headline Goal to the EU Battlegroups. (2014). Directorate-general for external policies of the Union. Directorate B. https://www.europarl.europa. eu/meetdocs/2009_2014/documents/sede/dv/sede030909noteesdp_/sede030909noteesdp_en.pdf

The French idea to defend Europe. https://klubjagiellonski.pl/2019/12/30/europejska-inicjatywainterwencyjna-czyli-francuski-pomysl-na-obrone-europy/\#

The new EU command post is in Cracow. http://polska-zbrojna.pl/home/articleshow/17733?t=Nowedowodztwo-UE-jest-w-Krakowie

The Polish Presidency of the Council of the European Union, Final Report on the Preparation and Duration of the Presidency. (2012). http://oide.sejm.gov.pl/oide/images/files/prezydencja/ Raport_koncowy.pdf

The situation in Poland after the elections to the European Parliament. https://ec.europa.eu/poland/ news/190624_wybory_pl 
Treaty on the European Union - consolidated text incorporating the changes introduced by the Treaty of Lisbon. OJ 2004.90.864/30.

Treaty on the Functioning of the European Union - consolidated version. (2016). https://eur-lex. europa.eu/legal-content/EN/TXT/?uri=celex\%3A12016ME\%2FTXT

Usewicz, T. (2017). Brexit i jego konsekwencje dla Wspólnej Polityki Bezpieczeństwa i Obrony Unii Europejskiej. Rocznik Bezpieczeństwa Międzynarodowego.

Wallström, M., \& Hultqvist, P. (2017). Vi vill agera för att stärka EU:s försvarssamarbete. Dagens Nyheter. http://www.regeringen.se/debattartiklar/2017/06/vi-vill-agera-for-att-starka-eus-forsvarssamarbete Węglarczyk, B. (2010).Na pożegnanie UZE.https://wyborcza.pl/1,75399,7901984,Na_pozegnanie_UZE. html

Wojciechowski, M. (2009). Kouchner u Sikorskiego i ambasadorów. https://wyborcza. pl/1,75398,6841908,Kouchner_u_Sikorskiego_i_ambasadorow.html

Zięba, R. (2005). Europejska Polityka Bezpieczeństwa i Obrony. Wydawnictwo Sejmowe.

Zięba, R. (2010). Główne kierunku polityki zagranicznej Polski po zimnej wojnie. Wydawnictwo Akademickie i Profesjonalne.

Zięba, R. (2018). Polityka bezpieczeństwa Polski. In R. Zięba (Ed.), Bezpieczeństwo międzynarodowe $w$ XXI wieku. Wydawnictwo Poltex Sp. z o.o.

Zięba, R. (2020). Poland's Foreign and Security Policy: Problems of Compatibility with the Changing International Order. Springer.

Zięba, R. (2012). Wspólna Polityka Zagraniczna i Bezpieczeństwa Unii Europejskiej. Wydawnictwa Akademickie i Profesjonalne Spółka z o.o.

Żurawski vel Grajewski, P.(2012). Bezpieczeństwo międzynarodowe. Wymiar militarny. Wydawnictwo Naukowe PWN. 